\title{
Morphological Changes of the Structures in the Air-Way due to Laryngeal Diseases
}

Kyozo Kikuchi, M.D.

Department of Otolaryngology, Nihon University School of Medicine, Tokyo

Electron microscopy was used to study the morphological changes of the tracheal epithelia in the laryngeal carcinoma. Nine humen tracheae were used for this study. Under the local anesthesia, tracheotomy was performed and a piece of the tracheal wall was removed. The specimen was treated by usual way for fixation, decalcification and cutting, then the tracheal epithelia with special reference to the cilia of the ciliated cells were observed with the aid of transmission and scanning electron microscopy. The results obtained were as follows:

1) The morphological changes of the tracheal cilia were compared with the clinical findings respectively. There were not always found on relation between serious grade of carcinoma and histological changes of the tracheal cilia.

s) The first morphological change of the cilium was observed as partial swelling of the cilium. Then arrangement of the cilia became irregular.

3) When pathological changes of the cilia were increased, adhesion and collapse of the cilia were found.

4) The author and his associates have investigated morphological changes of the tracheal walls due to air pollutants such as $\mathrm{SO}_{2}, \mathrm{NO}_{\mathbf{x}}, \mathrm{O}_{3}$, exhaust gas of gasoline motor car and others. Comparison of their findings and the results of this study was performed. It was a striking feature that the findings due to air pollutants were almost the same as those of carcinoma. The results above mentioned suggest that effects of chemical stimulation such as air pollutants were similar in appearance to those of physical stimulation such as air way stenosis due to carcinoma.

\section{研 究 目的}

ここにいう喉頭異常とは喉頭癌を意味するものと し, また気管壁とは, 本学会の特性からその代表とし て気管壁を選ばせて頂き, 研究を進めた。従ってこの 研究は, 喉頭癌における気管壁の形態学的変化をしら ベることを目的とした。

\section{研究対象ならびに研究方法}

研究対象は全部で 9 例であるが, TNM 分類に従っ て病変の程度によって配列すると表 1 となった。すな わち, 癌の大きさ, 病変の拡がり方, 声帯の運動性,

*日本大学医学部耳鼻咽喉科（主任：斎藤英雄教授）
リンパ節の触知，転移の有無など各症例によって異な っていた。

研究方法は, 局所麻酔の下に形の如く気管切開を行 なって気管を円形に開空し，その切除した気管をもっ て研究材料とした。材料は形の如く固定し, 脱水の 後, 処理し透過形および走查形電子顕微鏡によって観 察した。

\section{研 究 成 縝}

第 1 例は, 初診時右声帯に限局して癌が認められた ために, ブレオマイシンの局所に対する注入とコバル 卜照射の併用によって治療したいと考え，まず気管切 開を行った症例である。 
表 1 研 究 対 象

\begin{tabular}{c|c|c|c|c}
\hline No. & 姓 & 年齢 & 性 & 分 \\
\hline 1 & & 83 & 女 & 類 \\
2 & & 50 & 男 & $\mathrm{T}_{1} \mathrm{~N}_{0} \mathrm{M}_{0}$ \\
3 & & 73 & 男 & $\mathrm{T}_{2} \mathrm{~N}_{1} \mathrm{M}_{0}$ \\
4 & & 53 & 男 & $\mathrm{T}_{8} \mathrm{~N}_{0} \mathrm{M}_{0}$ \\
5 & & 62 & 男 & $\mathrm{T}_{3} \mathrm{~N}_{0} \mathrm{M}_{0}$ \\
6 & & 77 & 男 & $\mathrm{T}_{3} \mathrm{~N}_{0} \mathrm{M}_{0}$ \\
7 & & 59 & 男 & $\mathrm{T}_{3} \mathrm{~N}_{1} \mathrm{M}_{0}$ \\
8 & & 52 & 男 & $\mathrm{T}_{4} \mathrm{~N}_{1} \mathrm{M}_{0}$ \\
9 & & 64 & 男 & $\mathrm{T}_{4} \mathrm{~N}_{1} \mathrm{M}_{0}$
\end{tabular}

気管の電子顕微鏡所見では, 気管上皮は粘液によっ ておおわれている部分が多く, cilia は個々に独立し ておらず，幾つかが療着して集り，従って cilia の配 列の乱れが著明であった（図 4 )。

第 2 例は, 左声帯に癌が生じ運動性も若干障害され ていた。喉頭所見では第 1 例よりも癌は進行していた にも拘わらず, 形態学的には cilia の配列の乱れは少 なく, cilia の先端に 纎毛膜の膨隆を認めるのみであ った(図 2 )。

第 3 例は, 左声帯の辺縁部から更に声門下腔に向っ て癌が浸潤していた。形態学的に興味ある所見は, cilia の性状が部分的に大きく異なっていた点である。 すなわち, cilia の配列が乱れ (図 3), 夾雑物が付着 していた部分もあれば, cilia の配列の乱れの少ない 部分も認められた（図 1 )。なおこの部分の透過形電 子顕微鏡による観察では, 細胞ならびに cilia には病 変は認められなかった（図 9 )。

以上から,この症例では気管上皮細胞が次第に変性 に向っている過程にあると推察された。

第 4 例は, 初診の 2 年前から嗄声を訴え, 半年前よ り次第に増悪し，殊に初診時には左声帯が固定してい るために軽度の呼吸困難を訴えていた。気管上皮を観 察すると cilia の一部が短縮してその大小不同が認め られた。

第 5 例は, 2 カ月前より嗄声に気付いていたが左声 帯は正中位よりもむしろ若干健側に偏位して固定して いた。形態学的には,ゴプレット細胞に変化は認めら れなかったが, cilia の初期病変である 繊毛膜の膨隆 が認められた。

第 6 例の左声帯は正中位において固定しており, 肺 機能も低下していた。しかも咽喉頭に常に粘液がから み，疢を喀出することが困難であると訴えていた。 形態学的には, 気管の表面は粘液によっておおわれ
ているために上皮細胞の自由面があらわれておらず, 僅かに cilia の一部のみが配列を乱し，方向性を失っ ているのが認められた。Cilia の一部が変性し，互い に療着したりあるいは切断されていた（図 5，6）。

癌が最も進行していた第 9 例では, リンパ節は触れ 鱟下痛も加わっていた。この例では気管上皮の脱落と 瘾着とが混在していた（図 7，8)。

以上の研究成績をまとめると, 概ね次の通りである （図 $1 \rightarrow 8$ )。

初期变化は, 気管繊毛細胞の繊毛膜の膨化としてあ らわれる。これは cilia の先端に近く顆粒状になり， あたかも水泡が付着しているような形として認められ た。ついで cilia の配列が乱れ, cilia の大小不同, 瘾 合が生じ, 更に病変が進行すると, 粘液が気管上皮に 付着して上皮細胞をおおってしまう。このような時期 では繊毛運動は大きく障害されてしまい，気管に付着 した粘液の喀出困難となり, 病変が進行すると考えら れた。

以上, 気管壁の形態学的変化のうち, 特に繊毛細胞 と繊毛の変化を中心に述べたが, 全例を通して, 基底 細胞では, 光学顕微鏡上病変は認められなかった。

\section{考察}

喉頭癌の臨床所見と気管壁の形態学的変化とは，必 らずしも常に一致するとは限らなかった。これは癌の 発生部位とその抎がり方, 神経麻痺の有無による声門 の狭窄の度合いに応じて, 気流の量と質に変化をきた し, しかも胸部の異常所見の有無, 肺機能の状態, 更 にこれらの病変があった場合，その期間の長短，年齢 など幾つかの因子が複雑に組み合わされて気管壁の形 態に異常をきたすからであると考えられる。

著者は数年前より反回神経麻瘦の肺機能に及ぼす影 響についてしらべ, 本学会に発表してきたが, 反回神 経麻䍡が呼吸抵抗を増加せしめ，かつガス分析におい ても $\mathrm{PCO}_{2}$ と $\mathrm{PO}_{2}$ に少なから影響を与えることを 知った。喉頭癌により気道が変化し, 更に神経麻痺が 加わり，あるいは炎症性機転をも生ずれば，当然気管 における病変も増加してくると考えられる。

著者の教室では, 東京都公害研究所の協力を得て, 大気污染物質の吸入による気道の形態学的変化につい て研究を進めており, これまでに, 亜硫酸ガス, 窒素 化合物, オゾン, 自動車の排気ガス吸入による気道の 変化をしらべ報告してきた。これら気道の形態学的変 化は, 喉頭癌によって生ずる変化と非常に似ている成 績がえられたのは極めて興味が深いと考えられる。 
すなわち, 気道のうち気管繊毛に限って大気污染物 質と喉頭癌に㧍ける変化を比校してみると, それぞれ の初期変化は, 亜硫酸ガス吸入によるモルモットの cilia, オン゙ン吸入によるウサギの cilia, そして喉頭癌 によるヒトの cilia では, いづれも繊毛膜の膨隆とい ら形で認められた。このような一見水泡状の初期病変 を透過形電子顕微鏡でしらべると, 纎毛膜の変性によ って生じていることは明らかであり, 単なる付着物で はない。

次に病変が非常に進行した場合を比較してみたい。 自動車の排気ガス吸入によって生ずるモルモットの気 管上皮は, cilia の瘾合崩壊として認められたが，こ の所見は, 病変が最も進行したヒトの喉頭癌における 気管上皮の変性と非常によく似ていた。

以上から，喉頭癌と神経麻㾝によって生ずる気管の 形態学的変化は, あたかも亜硫酸ガス, 窒素化合物, オゾンのような刺激ガスという化学的刺激と同様に, 声門の狭少という物理的な刺激によって生ずるものと 考えられた。

\section{ま と め}

1. 喉頭癌 9 例について, その臨床所見と気管の形 態学的変化とを比較検討した。

2. 研究対象は50才より83才に至る男性 8 名女性 1 名であり, 病変は $\mathrm{T}_{1} \mathrm{~N}_{0} \mathrm{M}_{0}$ から $\mathrm{T}_{4} \mathrm{~N}_{1} \mathrm{M}_{0}$ に至るも
のであった。

3. 研究方法として，まず気管切開を行ない気管を 円形に開空し，その切除した気管をもって材料とし， 電子顕微鏡によって形態学的変化を観察した。

4. 気管纎毛の病変は，まず緎毛膜の膨隆としてあ らわれ,ついで繊毛の配列の乱れ，瘾合，崩壊の順と して認められ, 最も強い病変は, 気管上皮の脱落であ った。

5. このような変化は, 亜硫酸ガス, オゾン, 自動 車の排気ガス吸入実験の成績とよく似ていた。

以上から, 大気污染物質のよ 5 な化学的刺激と喉頭 癌による声門の狭窄といら物理的刺激とでは，それぞ れによって生ずる気管壁の変化は, 刺激源が異なって いても非常に相似た結果をもたらすことが明らかにさ れた。

稿を終るに臨み，本シンポジゥムに発表の機会を与 えられた会長萩原忠文教授ならびに司会の労をとられ た山本嶅教授に深謝します。また, 研究を進めるに当 り直接ご協力を頂いた教室員各位に感謝します。 なお，喉頭狭窄による動物実験の成績に関しては， 紙面の都合で省略し，他の機会に発表する予定です。

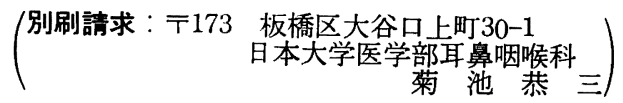


菊 池 恭三諭文 付図 (1)
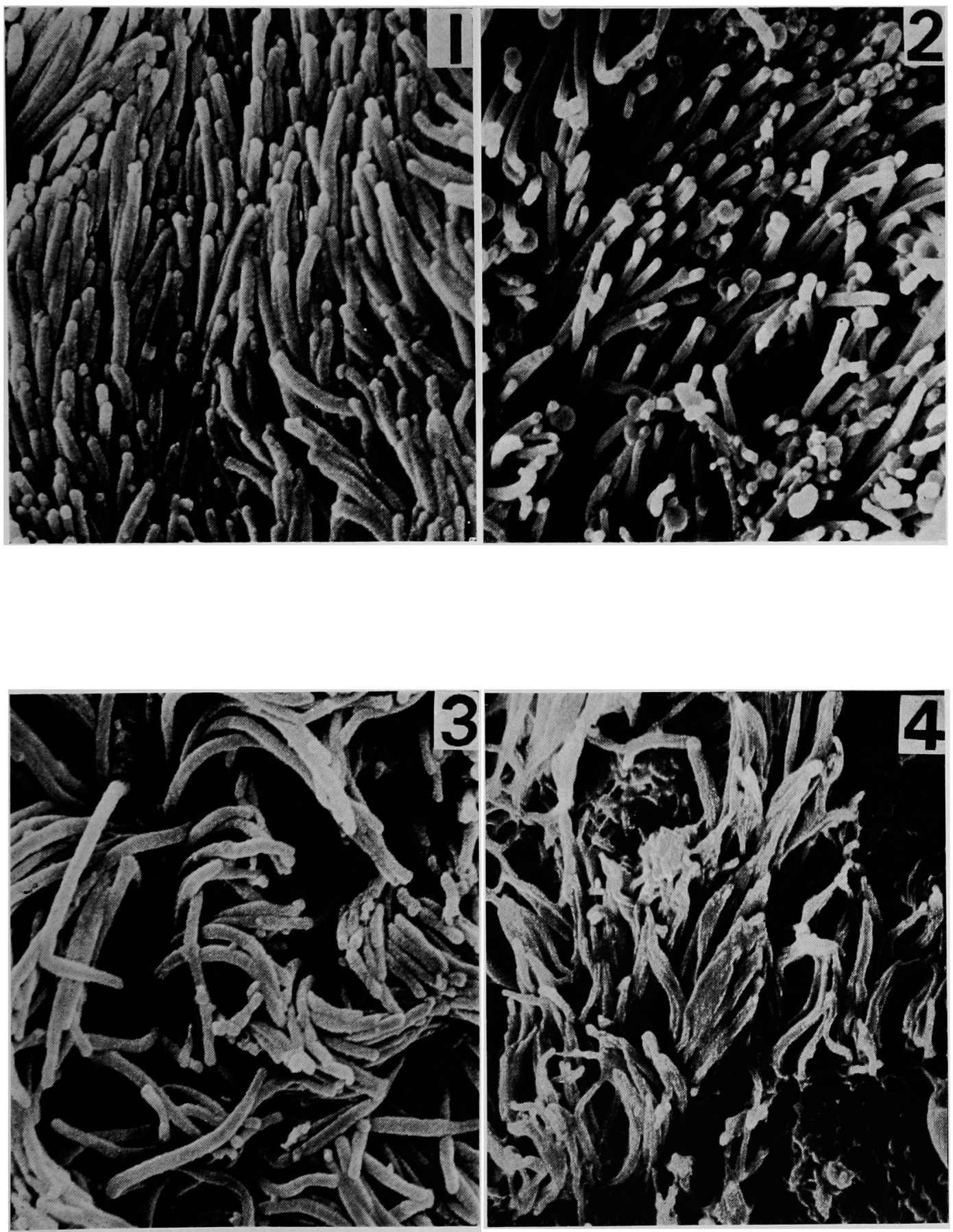
菊池恭三論文付図 (2)
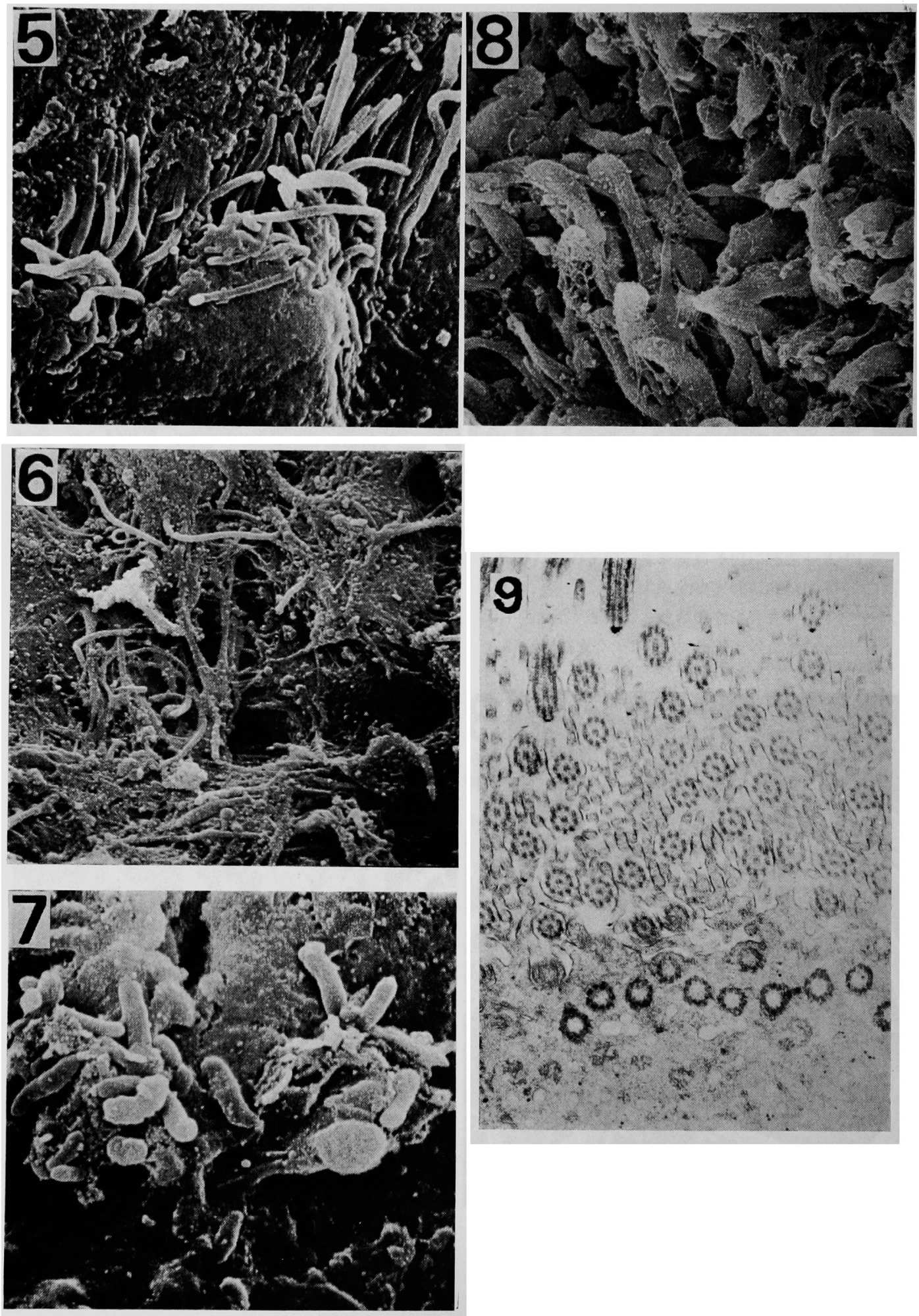